\title{
Communicating the status of volcanic activity: revising New Zealand's volcanic alert level system
}

\author{
Sally H Potter ${ }^{1 *}$, Gill E Jolly², Vincent E Neall ${ }^{3}$, David M Johnston ${ }^{4}$ and Bradley J Scott ${ }^{2}$
}

\begin{abstract}
The communication of scientific information to stakeholders is a critical component of an effective Volcano Early Warning System. Volcanic Alert Level (VAL) systems are used in many countries as a tool within early warning systems to communicate complex volcanic information in a simple form, from which response decisions can be made. Such communication tools need to meet the requirements of a wide range of end-users, including emergency managers, the aviation industry, media, and the public. They also need to be usable by scientists who determine the alert levels based on integration and interpretation of volcano observations and monitoring data.

This paper presents an exploratory review of New Zealand's 20-year old VAL system, and for the first time globally, describes the development of a VAL system based on a robust qualitative ethnographic methodology. This involved semi-structured interviews of scientists and VAL end-users, document analysis, and observations of scientists over three years as they set the VAL during multiple unrest and eruption crises. The transdisciplinary nature of this research allows the system to be revised with direct input by end-users of the system, highlighting the benefits of using social science methodologies in developing or revising warning systems. The methodology utilised in this research is applicable worldwide, and could be used to develop warning systems for other hazards.

It was identified that there are multiple possibilities for foundations of VAL systems, including phenomena, hazard, risk, and magmatic processes. The revised VAL system is based on the findings of this research, and was implemented in collaboration with New Zealand's Ministry of Civil Defence and Emergency Management in July 2014. It is used for all of New Zealand's active volcanoes, and is understandable, intuitive, and informative. The complete process of exploring a current VAL system, revising it, and introducing it to New Zealand society is described.
\end{abstract}

Keywords: Volcanic alert levels; Aviation colour code; Communication; New Zealand; Civil protection; Emergency management; Social science; Hazard; Early warning system

\section{Background}

\section{Volcano early warning systems}

Early Warning Systems for hazards can be defined as "the set of capacities needed to generate and disseminate timely and meaningful warning information to enable individuals, communities and organizations threatened by a hazard to prepare and to act appropriately and in sufficient time to reduce the possibility of harm or loss" (UN/ISDR 2009, p. 12). Within a Volcano Early Warning System (VEWS), monitoring data are collected and interpreted by scientists, the level of threat is determined, and the decision to alert end-users is made in a context of uncertainty (Fearnley 2013). Warning information must

\footnotetext{
* Correspondence: S.potter@gns.cri.nz

'GNS Science, 1 Fairway Drive, Avalon, Lower Hutt, New Zealand Full list of author information is available at the end of the article
}

be disseminated, and receivers of that information require the capability to respond for a VEWS to be effective (UN/ISDR PPEW 2006).

End-users of volcano information may include civil defence and emergency management personnel; local, regional and national government authorities; civil aviation; major land managers; lifelines and utilities agencies; local businesses, including tourism operators, and their clients; the media; potentially affected residents; and the general public. The wide range of end-users' roles and experiences results in differences in their information needs. For example, each of the civil aviation, agriculture, conservation, utility, and transport sectors may require information on ash. Due to the diverse purposes and decisions made by these end-users, information on the ash thickness and composition, its temporal and spatial distribution, 
variations in meteorological conditions, and chemical interactions (e.g., interactions between ash and water or soil) may be required (Ronan et al. 2000; Angrosino 2008).

New Zealand has a range of types of volcanoes that are considered active or potentially active, including stratocones (White Island, Tongariro/Ngauruhoe, Mt. Ruapehu, and Taranaki), caldera volcanic centres (e.g., Raoul, Macauley, and Mayor Islands; Rotorua, Okataina, and Taupo), and intraplate volcanic fields (Auckland, Kaikohe-Bay of Islands, and Puhipuhi-Whangarei), although some have not erupted for tens of thousands of years. The most recent eruptions were small explosive events which occurred at Tongariro (August and November 2012), and White Island (2012-2013). New Zealand's risk environments also differ, ranging from potentially high in the Auckland Volcanic Field, which is overlain by a city of 1.4 million people, to relatively low at the unpopulated Mayor and Macauley Islands. Thus, it is necessary for any communication of scientific information to be effective, timely, and understandable to a diverse range of end-users in various socio-economic environments.

GNS Science monitors New Zealand's volcanoes through the GeoNet project and is responsible for issuing scientific advice on geohazards, as stated in a Memorandum of Understanding with the Ministry of Civil Defence and Emergency Management (MCDEM; GNS Science and MCDEM 2009; Scott and Travers 2009). There are a number of rapid detection monitoring and warning systems and alarms, including the Eruption Detection System (EDS) at Ruapehu, which is designed to detect eruptions and trigger automated lahar warning messages to the local ski area; the Eastern Ruapehu Lahar Alarm and Warning System (ERLAWS), which warns about lahars produced by the collapse of the Crater Lake natural dam (Sherburn and Bryan 1999; Leonard et al. 2008; Scott and Travers 2009); and the Tongariro Eruption Detection system (TEDS) developed following the 2012 eruptions at Te Maari crater, Tongariro. Both EDS and ERLAWS are operated, monitored, and maintained by the primary land manager of Mt. Ruapehu, the Department of Conservation, with support from Ruapehu Alpine Lifts Limited (a ski field company), and GNS Science (Leonard et al. 2008).

\section{Volcanic information communication tools}

The dissemination of scientific information and communication between agencies is critical to the effective management of a volcanic crisis (e.g., Fiske 1984; Peterson and Tilling 1993; Newhall and Punongbayan 1996; McGuire et al. 2009). In New Zealand, scientific discussions are held by GNS Science in collaboration with university scientists, and information is disseminated in a variety of formats.

A balance needs to be achieved between limiting errors in measurements and estimates of risk and eruption forecasts, and maintaining credibility and specificity, in order to retain trust and promote actions by end-users (Voight 1990). In order for local authorities, media, and response personnel to understand and believe the issues facing a community, effectively prepare for them, and heed warnings, scientific information needs to be in an appropriate style, and contain appropriate content (Mileti and Sorensen 1990).

It has been identified that locally appropriate communication methods should be established for the distribution of warnings, in order to be effective (IDNDR Early Warning Programme Convenors 1997). Volcanic information in New Zealand is communicated using a number of methods and tools. A one-way communication of information (sometimes with prior multi-directional input) is provided before, during, and after volcanic crises through presentations by scientists during conferences, workshops, and public lectures; on websites; in scientific and non-scientific publications; and via the media. Additionally, multi-agency meetings provide the opportunity to present information to key stakeholders, including at local, regional and national Civil Defence and Emergency Management (CDEM) sector meetings, and volcano advisory group meetings. Likewise, emails, faxes, pager alerts, and SMS text messages provide oneway scientific information to registered end-users during crises or changes in volcanic activity. Volcanic ash impact posters (a product of the Volcanic Impact Study Group (2014), commissioned by the Auckland Lifelines Group) provide accessible information for critical infrastructure stakeholders.

Long-term hazard maps have been created for some of the more active volcanoes, based on geological evidence of past eruptions. Event-specific hazard maps are created before or during unrest, depending on the situation, likely vent location, and the style and magnitude of the potential eruption. Recently, social media, and 'ask an expert' interactive online sessions have allowed question and answer sessions from the public in real-time. Informal conversations during meetings, workshops, or on the telephone provide end-users with more specific information from volcanologists, with the opportunity for two-way communication.

GNS Science issues information on volcanic activity on the GeoNet website (2014), social media, and through Volcanic Alert Bulletins (VABs), which are received by MCDEM and other registered agencies and individuals, including responding agencies, the media, and the public. MCDEM further disseminates the VABs through the National Warning System as an Advisory or Warning message (MCDEM 2006).

The International Civil Aviation Organization (ICAO) Aviation Colour Code (ACC) was adopted by New Zealand in order to alert the aviation industry to changes 
in the status of volcanoes (Lechner 2012; Figure 1). When the ACC is changed by GNS Science, a Volcano Observatory Notice for Aviation (VONA) is communicated to New Zealand's Volcanic Ash Advisory Centre at MetService in Wellington, who further disseminate the information to the aviation sector (Lechner 2012).

\section{Volcanic alert level systems}

Volcanic Alert Levels are a tool within a VEWS that simplify the communication of volcanologists' interpretation of data (Newhall 2000). The VAL is disseminated with supporting information that provides more specific details and local context to enable responding agencies, the public, and other stakeholders to make informed decisions (Fearnley 2011). VALs range in their use of colours, words, symbols, and numbers; inclusion of forecasting or predictive language; structure; number of levels; weighting towards unrest vs. eruptions; and the level of scientific jargon used.

VAL systems need to be carefully managed to provide adequate warning of an impending eruption, without resulting in too many 'false alarms' (Newhall 2000). Repeated 'false alarms' can impact the credibility of the source of the information (Dow and Cutter 1997). Nonetheless, scientists must be willing to freely move between VALs depending on the volcano's activity without being influenced by political pressure (Newhall 2000), despite the difficulty of avoiding this (Metzger et al. 1999; Fearnley, 2013).

The first use of a VAL system in New Zealand was that created for a national exercise called Nga Puia, in 1992. A post-exercise review identified that the use of colours in both the VAL system and the 'control zones' used in the exercise created confusion, and that there was a need for more useful public advice in the system (Martin 1992). New Zealand's first official VAL system (referred to hereafter as 'VAL V1') was created in 1994 based on the findings of the review process (according to correspondence and meeting notes stored in the GNS Science archives), and on lessons learnt from the Rabaul Caldera (Papua New Guinea) unrest episode and eruption response in the 1980s and 1990s (Nairn and Scott 1995). VAL V1 was first used during increased activity at Mt. Ruapehu in December 1994. This experience caused the identification of a number of issues with the system, including the need for a level that recognised 'no unrest', and conflicting definitions within a single level for different volcanoes (detailed further in Potter 2014).

A revised VAL system was adopted in September 1995 ('VAL V2'), one week before the onset of the 1995-96 eruption episode at Ruapehu, and remained in use until June 2014. VAL V2 was divided into two systems (Figure 2) - one for frequently active volcanoes (including Ruapehu, Tongariro, and White Island), and the other for reawakening volcanoes (including Taupo Volcanic Centre, Okataina Volcanic Centre, Auckland Volcanic Field, and Taranaki volcano). The VAL system is located in the MCDEM Guide to the National CDEM Plan (MCDEM 2006; Section 19.4.2). VAL V2 was based on the volcano's current status, and was not necessarily predictive (Scott and Travers 2009). Determining the VAL in New Zealand is the statutory responsibility of GNS Science (as stated in the Memorandum of Understanding between GNS Science and MCDEM 2009). New Zealand's VAL system is for the communication of information derived by scientific monitoring and observations, and not for information relating to mitigation advice, such as areas of evacuation (unlike in other countries, such as a VAL system used in Mexico; De la Cruz-Reyna and Tilling 2008). This is because roles and responsibilities are clearly defined between scientific agencies and emergency response in New Zealand, meaning that it would not be appropriate for GNS Science to issue response information. Changes in the VAL are disseminated in VABs, with accompanying situation-specific information.

This paper describes the research used to explore VAL V2, including the meanings placed on the system by scientists and end-users, decisions made based on the information in the VAL system, and how it is used in practice. Based on this research, a revised version of the system has been developed (VAL V3). The process used to establish this system is also described.

\begin{tabular}{|c|c|}
\hline ICAO Colour code & Status of activity of volcano \\
\hline GREEN & $\begin{array}{l}\text { Volcano is in normal, non-eruptive state. or, after a change from a higher alert level: Volcanic } \\
\text { activity considered to have ceased, and volcano reverted to its normal, non-eruptive state. }\end{array}$ \\
\hline YELLOW & $\begin{array}{l}\text { Volcano is experiencing signs of elevated unrest above known background levels. or, after a } \\
\text { change from higher alert level: Volcanic activity has decreased significantly but continues to be } \\
\text { closely monitored for possible renewed increase. }\end{array}$ \\
\hline ORANGE & $\begin{array}{l}\text { Volcano is exhibiting heightened unrest with increased likelihood of eruption. } \\
\text { or, Volcanic eruption is underway with no or minor ash emission [specify ash-plume height if } \\
\text { possible]. }\end{array}$ \\
\hline RED & $\begin{array}{l}\text { Eruption is forecasted to be imminent with significant emission of ash into the atmosphere } \\
\text { likely. or, Eruption is underway with significant emission of ash into the atmosphere [specify } \\
\text { ash-plume height if possible]. }\end{array}$ \\
\hline
\end{tabular}

Figure 1 The ICAO Aviation Colour Code for volcanic activity. Source: Lechner (2012). 


\begin{tabular}{|c|c|c|c|c|}
\hline \multicolumn{2}{|c|}{$\begin{array}{l}\text { Frequently active cone volcanoes } \\
\text { White Island, Tongariro-Ngauruhoe, Ruapehu, } \\
\text { Kermadecs }\end{array}$} & \multirow{2}{*}{$\begin{array}{l}\text { VOLCANIC } \\
\text { ALERT } \\
\text { LEVEL }\end{array}$} & \multicolumn{2}{|c|}{$\begin{array}{l}\text { Reawakening volcanoes } \\
\text { Northland, Auckland, Mayor Island, Rotorua, } \\
\text { Okataina, Taupo, Egmont/Taranaki }\end{array}$} \\
\hline Volcano status & Indicative phenomena & & Indicative phenomena & Volcano status \\
\hline $\begin{array}{l}\text { Usual dormant, or } \\
\text { quiescent state }\end{array}$ & $\begin{array}{l}\text { Typical background } \\
\text { surface activity, } \\
\text { seismicity, deformation } \\
\text { and heat flow at low } \\
\text { levels. }\end{array}$ & 0 & $\begin{array}{l}\text { Typical background } \\
\text { surface activity; } \\
\text { deformation, } \\
\text { seismicity, and heat } \\
\text { flow at low levels. }\end{array}$ & $\begin{array}{l}\text { Usual dormant, or } \\
\text { quiescent state. }\end{array}$ \\
\hline $\begin{array}{l}\text { Signs of volcano } \\
\text { unrest }\end{array}$ & $\begin{array}{l}\text { Departure from typical } \\
\text { background surface } \\
\text { activity. }\end{array}$ & 1 & $\begin{array}{l}\text { Apparent seismic, } \\
\text { geodetic, thermal } \\
\text { or other unrest } \\
\text { indicators. }\end{array}$ & $\begin{array}{l}\text { Initial signs of } \\
\text { possible volcano } \\
\text { unrest. No eruption } \\
\text { threat. }\end{array}$ \\
\hline $\begin{array}{l}\text { Minor eruptive } \\
\text { activity }\end{array}$ & $\begin{array}{l}\text { Onset of eruptive } \\
\text { activity, accompanied by } \\
\text { changes to monitored } \\
\text { indicators. }\end{array}$ & 2 & $\begin{array}{l}\text { Increase in number } \\
\text { or intensity of unrest } \\
\text { indicators (seismicity, } \\
\text { deformation, heat flow } \\
\text { and so on). }\end{array}$ & $\begin{array}{l}\text { Confirmation of } \\
\text { volcano unrest. } \\
\text { Eruption threat. }\end{array}$ \\
\hline $\begin{array}{l}\text { Significant local } \\
\text { eruption in } \\
\text { progress }\end{array}$ & $\begin{array}{l}\text { Increased vigour of } \\
\text { ongoing activity and } \\
\text { monitored indicators. } \\
\text { Significant effects } \\
\text { on volcano, possible } \\
\text { effects beyond. }\end{array}$ & 3 & $\begin{array}{l}\text { Minor steam } \\
\text { eruptions. High } \\
\text { increasing trends of } \\
\text { unrest indicators, } \\
\text { significant effects } \\
\text { on volcano, possible } \\
\text { beyond. }\end{array}$ & $\begin{array}{l}\text { Minor eruptions } \\
\text { commenced. } \\
\text { Real possibility } \\
\text { of hazardous } \\
\text { eruptions. }\end{array}$ \\
\hline $\begin{array}{l}\text { Hazardous local } \\
\text { eruption in } \\
\text { progress }\end{array}$ & $\begin{array}{l}\text { Significant change to } \\
\text { ongoing activity and } \\
\text { monitoring indicators. } \\
\text { Effects beyond volcano. }\end{array}$ & 4 & $\begin{array}{l}\text { Eruption of new } \\
\text { magma. Sustained } \\
\text { high levels of unrest } \\
\text { indicators, significant } \\
\text { effects beyond } \\
\text { volcano. }\end{array}$ & $\begin{array}{l}\text { Hazardous local } \\
\text { eruption in } \\
\text { progress. Large- } \\
\text { scale eruption now } \\
\text { possible. }\end{array}$ \\
\hline $\begin{array}{l}\text { Large hazardous } \\
\text { eruption in } \\
\text { progress }\end{array}$ & $\begin{array}{l}\text { Destruction with } \\
\text { major damage beyond } \\
\text { volcano. Significant risk } \\
\text { over wider areas. }\end{array}$ & 5 & $\begin{array}{l}\text { Destruction with major } \\
\text { damage beyond active } \\
\text { volcano. Significant } \\
\text { risk over wider areas. }\end{array}$ & $\begin{array}{l}\text { Large hazardous } \\
\text { volcanic eruption } \\
\text { in progress. }\end{array}$ \\
\hline
\end{tabular}

Figure 2 New Zealand's VAL system (VAL V2), used between 1995 and 2014. Reproduced from the Guide to the National CDEM Plan (MCDEM 2006; Section 19.4.2).

\section{Methodology}

\section{Research framework}

A qualitative research framework was utilised to explore New Zealand's VAL system (VAL V2), as it enables the recognition of underlying meanings and reasons behind processes and choices more effectively than the use of more traditional quantitative research methods. This allows an understanding to be built based on listening to participants' ideas (Creswell 2003). The use of qualitative research methods for volcanology issues has increased in popularity over time, with examples including research by Mader and Blair (1987), Paton et al. (1998), Metzger et al. (1999), Cronin et al. (2004), Haynes et al. (2007, 2008), Donovan et al. (2012a, b), and Fearnley (2011, 2013).

The naturalistic setting used in this research (i.e., participants' normal places of work) permitted the collection of data to take place in an environment familiar to the participants, and promoted the inclusion of the local context as events were observed in real time (e.g., Denzin and Lincoln 1994; Miles and Huberman 1994).
A transdisciplinary approach was utilised, in which aspects of the disciplines of volcanology, communication, and emergency management were merged into a single approach (as described by Horlick-Jones and Sime 2004). The inclusion of the opinions and knowledge of practitioners who use the VAL system in the development of a new, more effective system further demonstrates the transdisciplinarity of this research (as defined by Balsiger 2004).

\section{Research methods}

An ethnographic methodology was used, which involves the study of a group of people and their culture (Patton 2002). In this research, the group of people includes those that use the VAL system in New Zealand, including volcanologists at GNS Science. Understanding the culture within the volcanology department at GNS Science focussed on aspects relating to the determination of the VAL. Tacit knowledge is difficult to transfer between people, and is best obtained by being immersed 
into a group of people who have it (Collins \& Evans, 2007). It is an important aspect of this ethnographic research, as many of the processes influencing VAL system decisions in New Zealand stem from tacit knowledge. A genuine understanding of the VAL system and how it is used was built through multiple research methods within this ethnographic framework, and included interviews, participant observations, and document analysis.

Semi-structured interviews were conducted with 19 scientists and 13 end-users of the VAL system between mid-2011 and early 2012. Interviews are a method used to obtain participants' opinions, thoughts, and experiences. They enable the researcher to become aware of the internal thought processes of participants, which observations alone cannot do (Patton 2002). Participants were identified through purposeful sampling (i.e., the intentional selection of people who fill roles that use the VAL system), reputational case selection (i.e., people recommended by other participants and experts in the field), and typical case sampling (i.e., people whose roles are more removed from the field of volcanic management but who may be called upon during future events), as defined by Miles and Huberman (1994). Scientist participants were from GNS Science (including technicians, scientists and management) and multiple universities in New Zealand. End-user participants were from local and regional CDEM organisations, MCDEM, civil aviation, the insurance sector, and a major land management agency. Interviews ranged in length from 30 to 90 minutes, and took place face-to-face. The interview questions focussed on obtaining the participants' perspectives of the VAL system that was in use (VAL V2). Thematic analysis of the transcribed interviews involved coding and the identification of themes (Braun and Clarke 2006), which created a framework for further discussions and drawing conclusions. As only a sample of the complete end-user population was able to be included as participants in this research, the findings may not be representative of the wider population.

Participant observations (e.g., Adler and Adler 1994) of the VAL decision-making process occurred within GNS Science (at Wairakei Research Centre). Participant observation is conducted through the immersion of the researcher into a willing community to experience ordinary events (Angrosino 2008). In essence, it is the experiencing of naturally occurring events by the researcher (Wolcott 1999). The focus of observations in this research was on the culture of GNS Science volcanology staff relating to their use of the VAL system (VAL V2), and the identification of improvements which could be made to the table that describes the VAL. The duration of immersion in the GNS Science community was three years, from August 2010 to August 2013. After the initial research planning stage and completion of the ethics approval processes, participant observations contributing towards the findings of this research took place between May 2011 and August 2013. The long duration of the observations allowed attendance at countless scientific meetings (including weekly volcano monitoring meetings and crisis response meetings), as well as those involving end-users and the public. The volcanology staff members at GNS Science were well aware that they were being observed, and they signed ethics consent forms. An active membership role of observation, involving participating in the groups' activities and taking on responsibilities (Adler and Adler 1994), was assumed in this research. The presence of an observer may influence the behaviour of research participants, and the process of observation is inescapably selective because the researcher constantly chooses what to register and record (Miles and Huberman 1994; Angrosino 2008). On the rare occasion that a video camera or voice recorders were used some people changed their behaviour (including sitting where they were not visible by the camera, and seemingly censoring comments). However, due to the long time period of the observations and small proportion of discussions being recorded, the effect of the presence of an observer on the findings appeared to be insignificant. The benefits of including observation as a research method to validate interview findings are substantial. Findings based on the interview and observation methods are influenced by the participants involved in the research. Therefore they may not necessarily be representative of past or future scientist and end-user groups.

Document analysis is particularly useful to gain insight into historical events, as the documents were written closer to the time of the event, and therefore may be more accurate than recollections during retrospective interviews. A relatively informal approach to document analysis was utilised in this research due to the often subsidiary and complementary role of this method (Peräkylä 2008).

Document analysis was used in this research to contribute towards:

1) The creation of interview questions

2) Analysis of how the VAL system (VAL V2) is used by end-users (using end-user response planning manuals)

3) Analysis of how scientists determine the VAL (including receiving emails relating to participants' thoughts on the VALs)

4) Understanding historical events involving the VAL system

5) The development of foundations for future VAL systems (including detailed thoughts recorded in documents by participants).

Documents analysed included VABs for VAL changes before, during, and after previous events; end-user volcanic contingency plans (including those from regional 
CDEM Groups, local/district CDEM and the Civil Aviation Authority); and documents and emails written by participants containing their opinions on potential VAL systems for New Zealand and those used at other volcanoes worldwide.

The fortuitous occurrence of volcanic crises in New Zealand in mid- to late-2012 consisted of coinciding unrest (at Ruapehu, Tongariro and White Island) and eruptions (at Te Maari crater on Tongariro, and White Island) after years of quiescence. These events provided an ideal structure to this research, of pre-crisis interviews; participant observations and ethnographic informal conversations during the crisis; and feedback by participants on research findings after the events. The use of these multiple methods also enabled triangulation, one of the strategies commonly used in ethnographic research to increase the validity of the research through the strengths of one method compensating for the weaknesses of another (Wolcott 1999; Patton 2002; Creswell 2003). Additionally, initial findings were triangulated through member checking (e.g., Stake 1995), involving the dissemination of detailed research findings and a short summary document to all participants for feedback via email. Further potentially interested end-users and scientists who are likely to be affected by the research findings were also included in this process. Participants were asked to provide general feedback on the findings, and to rank the five example VAL systems described in section 3.4 in the order of their preference. Feedback was received by 43 per cent of those who received the findings (20 out of 47), 17 of whom provided their foundation preference, including eight end-users and nine scientists. This feedback was incorporated into the final results.

Ethnography is the "business of inquiring into other people's business" (Wolcott 1999, p. 284). It is this process that can potentially harm participants in ways that are not foreseen. Institutional ethics committees provide safeguards to ensure research is undertaken without harming participants' health and wellbeing (Corbin and Strauss 2008). In this research, the risk to participants was carefully considered, and a low risk notification was accepted by the Massey University Ethics Committee (New Zealand) prior to the collection of data. Participants in this research and their views are kept anonymous, hence why we are unable to provide more details on which organisations the participants are from due to the small size of the volcano community in New Zealand. Quotes in this paper are attributed at the level of scientists ('Sc') and end-users ('EU').

For further details relating to the methodology, specific research methods utilised, details of limitations, and meetings attended, refer to Potter (2014). Based on these methodologies, the research findings are presented in the following section, and relate to the VAL system used in New Zealand between 1995 and 2014 (i.e., VAL V2). The findings contributed towards the subsequent development of the revised system (VAL V3), which was implemented in July 2014.

\section{Results and discussion}

\section{Establishing the context}

The research participants reported during the interviews that they were predominantly satisfied with the VAL system (all references to the VAL system in this results section refer to VAL V2, unless stated otherwise); however, some recognised the need to review the system to ensure it is as effective as possible. The need for a number of changes was identified, as discussed further below. By integrating participants' interview responses, the purpose of the VAL system was established to be a communication tool used by the scientists at GNS Science to enable endusers to quickly understand the current state of activity at the volcanoes, from which they can decide their response. This has similarities to the goals of the U.S. Geological Survey VAL system (Gardner and Guffanti 2006).

\section{Relationship between end-users and the VAL system}

Establishing end-users' information needs and how they use the VAL system are important elements of constructing effective scientific information products. Endusers indicated during interviews that they place more emphasis on person-to-person communication with scientists than they place on the VAL system. For example:

\section{"I would not be reliant on numbers from the scale...If [activity at the volcano] was local...I'd be wanting a lot more detail. I wouldn't even be looking at this [the VAL table] for my purposes internally. I'd make a phone call" (EU).}

The desire for person-to-person communication supports the findings by Fearnley (2011) and Sorensen and Gersmehl (1980). It emphasises the importance of scientists to be available to talk to end-users, and maintain effective relationships both during crises and periods of quiescence. Within the VAL system, levels relating to volcanic unrest were found to be more useful for endusers than levels relating to eruptions, as the former is when key response decisions are made. This finding may be influenced by a lack of experience of on-going and large eruptions by many end-users in New Zealand.

Some end-users stated that they often did not read VABs if the VAL had not changed, as it was seen to be "reconfirming" the current level. This is an important finding as the scientists place emphasis on supplementary information included in the VABs to provide situationspecific details. For example, the VAL might remain at 
level 1 (volcanic unrest), but an eruption may be forecast to be imminent and this information would be stated in the VAB. This further emphasises the need to use other communication methods (such as phone calls) to ensure important messages have been received. It suggests that including eruption forecasting into future VAL systems should be considered. It also indicates that adding a second level to the VAL system recognising heightened volcanic unrest may be beneficial, to differentiate those situations from the more commonly-occurring minor volcanic unrest episodes.

Of those end-user organisations that have detailed contingency plans for volcanic crises, some plans state that end-users will base their decisions on the level of volcanic activity (irrespective of the VAL), while others have actions more firmly associated to the VAL. Of the latter, most planned actions are fairly generic (such as "seek scientific advice" or "review plans"). An example of a more definite relationship between end-user plans and the VAL is in civil aviation flight restrictions around volcanoes. The VAL (not the ACC), is used to determine the size of the Volcanic Hazard Zones for aviation in New Zealand (Lechner 2012). Findings from observations and interviews in this research indicated that scientists' knowledge of end-user response actions for each VAL may influence their decision-making in determining the VAL. For example, in a situation where the level of activity is close to the thresholds between VALs and there is a high level of uncertainty relating to the outcome of an event, some scientists may hesitate to vote for a change in the VAL due to the risk of a 'false alarm'. Instead, they may wait for "confirmation" in the form of an indication of the presence of shallow magma, to avoid end-users responding in a manner that scientists believe is inappropriate. Other scientists may vote to raise the VAL to exercise precaution for public safety and prompt a response. This demonstrates the subjectivity imposed on what at first glance appears to be a relatively objective VAL system, and has interesting potential implications on the issue of roles and responsibilities between scientists and decision-making end-users.

\section{Review of structure and content of the VAL system}

The research participants recognised the need for New Zealand's VAL system to accommodate a wide range of volcano types and potential eruption magnitudes, unrest intensity, dormancy periods, eruption and hazard characteristics, and risk environments.

\section{Structure of the VAL system}

The VAL system was perceived by some interviewees as being too complicated and unclear with too many words, columns, and multiple duplications. The simplification of the overall structure was seen as being beneficial; "everyone wants it as simple as possible" (EU). While the content was the same, the appearance of the table varied between the Guide to the National CDEM Plan (MCDEM 2006) and the GeoNet website (2014), with the former presenting the information in one table (as shown in Figure 2), and the latter presenting the information in two separate tables. This was thought to be inconsistent and created confusion over whether they were the same system.

A participant suggested that reversing the order of the numbers so that the lowest level (0) is at the bottom of the table and the highest level (5) is at the top would enable the levels within the VAL system to increase from the bottom to the top as the volcano increases in activity.

The VAL system uses a numeric scale ranging from 0 to 5. No participants supported an increase in the number of alert levels, and some stated that they would prefer fewer. However, as some participants wanted three levels for eruptions to help position the scale of activity; two levels of unrest to differentiate between minor and heightened unrest; and one base level for the currently inactive volcanoes, the overall number of levels should remain the same. The need for a second level representing heightened unrest was made clear by participants, e.g., "for the frequently active cones there's very little flexibility; we're at 1 for Ruapehu and White [Island]. There's nowhere to go until it erupts, there's no way of signalling that we think it's in a heightened state of unrest likely to lead to eruption... so that's a big, big issue" (Sc). An additional unrest level is thought to enable the significance of the activity to be a more effectively communicated, and help emergency managers to undertake decisionmaking, preparations, and evacuations (if necessary) before an eruption occurs.

Some end-user participants stated during the interviews that they find it useful to position the level of volcanic activity in respect to the range of potential activity (0 to 5 ). This implies that the VAL system is being used as a linear, equal-interval scale, which was also identified by Fearnley $(2011,2013)$ for the USGS VAL system. If this is the case, then the difference in the level of activity between, for example, alert levels 1 and 2 will be perceived to be the same as the difference in the level of activity between alert levels 4 and 5 . However, the classes indicated by the equal intervals are unspecified and may include intensity or magnitude of unrest and eruptive activity, size of the area involved, hazard or danger, time to be spent at each level, and/or time before an eruption. Despite this potential for confusion, the majority of interview participants were satisfied with this numeric system, and preferred it to other options for labelling levels, such as colours, symbols, and words.

The division of New Zealand's VAL system (VAL V2) into two parts - one for reawakening volcanoes and the 
other for frequently active volcanoes - was seen by some participants to "confuse the issue and make it more complex than it needs to be" (Sc). The definitions of the levels are slightly different between the two systems, which may cause issues during the future when two volcanoes are on the same level but displaying different levels of activity. Reawakening volcanoes changing sides of the VAL table as they become more frequently active was also identified by participants as being a potential issue. The dynamic and undefined criteria used to place volcanoes in either group increases the likelihood for this to occur. Various other factors on which to base separate VAL systems were suggested by participants and identified by the researchers, as well as the possibility of developing a VAL system for each of New Zealand's active volcanoes. However, most participants specifically stated that they would not want to "overcomplicate it, by having too many" (Sc) systems. This is particularly due to the relatively small number of people that are involved with volcano-related issues in New Zealand, many of whom would need to use multiple VAL systems (including the public). The need for the VAL system to be used as a simple communication tool very likely outweighs any benefits of multiple tailored and more detailed VAL systems. In order for a single VAL system to be an effective communication tool for multiple very different volcanoes, the terms used in the revised version of the VAL system required very careful thought, and a certain degree of flexibility. In their research on standardisation of the U.S. VAL system, Fearnley et al. (2012) highlighted the importance of the local context, particularly for variances in hazards, institutional practices, and social settings. They state that a standardised VAL system can successfully operate if the communication product is effectively developed and utilised. This supports the integration of New Zealand's two VAL systems into one for all volcanoes, particularly as there is only one volcano observatory in New Zealand.

The inclusion of the indicative phenomena information in the VAL system (Figure 2) was questioned by some participants. The purpose of its inclusion was identified by participants to be 1) for scientists to use as a guideline for determining which alert level is most appropriate, and 2) to provide end-users with more information on what the volcano status means. Some end-users found the indicative phenomena information helped them interpret what the volcano status information means; "having [the indicative phenomena] in here is a help, another way of passing on further information to people" (EU). However, other end-users found the terminology to be incomprehensible, and would prefer a simpler system that is easier to immediately understand. Scientists reported having lengthy discussions and delays in decision-making as a result of debating the indicative phenomena. The descriptions in those columns were seen as being too detailed, and reflect little in the way of interpretation of magmatic processes. A suggestion was made by participants to replace the indicative phenomena columns with more useful information (such as a description of hazards) for end-users, to assist them with response decision-making.

\section{Content of the VAL system}

CDEM personnel need to quickly and accurately comprehend often complex scientific information for rapid response decision-making during a volcanic crisis. In part, this understanding can be developed through education, training, and open communication with scientists prior to a crisis, however it is also greatly influenced by the information these end-users receive during a crisis. Often, instead of the (usually important) scientific details, it seems the overall impression of the level of threat, and little phrases and analogies remembered by an end-user are quite influential to the overall multiagency response to the situation. The information contained in scientific communication tools such as the VAL system is seen by participants as an important element in maintaining consistent messages across all levels of communication.

The VAL system was thought by participants to be too complex and "verbose" (EU), to the point that end-users were discouraged to read it: "If there's too much in there, to be honest with you, you're not going to read it... it needs to be probably a one or a two liner with a very clear basic description" (EU). This is particularly the case due to the infrequency of volcanic eruptions limiting the end-users' knowledge and experience, as identified by this end-user participant: "Volcanoes don't [erupt] very often, [so] it is easy to be complacent about it. So when it does happen, the message ... needs to be simple, clear, and easily understood so people can actually act on that information. Because there is a risk if you have that information in too complex a form, that people miss the message" (EU).

It was identified by participants that a balance between descriptions being short enough but as unambiguous as possible is required. This finding is supported by Fearnley (2011), and general communication guidelines described by Mileti and Sorensen (1990), Newhall (2000), and De la Cruz-Reyna and Tilling (2008). The need to simplify the system through minimising the number of words and level of jargon supports the removal of the indicative phenomena column in VAL V3.

Participants stated that careful consideration of all content within the system was required to minimise any misinterpretation and confusion (such as for the term 'significant' used in VAL V2). This would also ensure that it was effective during both escalation and deescalation of a volcanic crisis, as well as for long periods of time spent at a single level. 


\section{Foundations of VAL systems}

The 'foundation' of the VAL system is essentially the theme used to divide the levels. VAL systems are a social construct that divide the continuous volcanic unrest and eruptive activity into a number of simplified categories to aid rapid understanding for response decision-making by nonscientists. VAL V1 and VAL V2 divide those categories based on a foundation of the intensity of volcanic activity (i.e., currently occurring phenomena). A phenomenonbased system separates levels based purely on the intensity of volcanic activity, regardless of where the volcano is situated in relation to society, and what the likelihood is of the events to occur. Aspects of volcanology and scientific knowledge have developed substantially in the 20 years since the VAL system (VAL V1) was first established in New Zealand (e.g., Scott and Travers 2009), along with a paradigm shift of acknowledging societal needs in the communication of scientific information (e.g., Fischhoff 1995; Barclay et al. 2008). According to participants, these developments prompt the need to carefully consider whether a phenomenon-based system is still appropriate.

This research has identified that the foundation of a VAL system does not have to be restricted to the intensity of current volcanic activity. Five foundations on which to base a VAL system were identified; some were suggested directly by research participants, while others are the result of analysis and interpretation of the interview, observation, and document analysis data. The foundations are phenomena, magmatic processes, hazard, and risk, as well as a multi-foundation system. Alternative foundations may also be appropriate in other countries including emergency response actions, particularly representing areas of evacuation. As mentioned earlier, because the VAL is currently determined by scientists in New Zealand, an emergency response-based VAL system would not be suitable.

Depending on which foundation is used, the levels in a VAL system might represent different intensities of volcanic activity, as demonstrated in Figure 3. In this figure, the levels in the hazard-based system are defined according to increasing likelihood of volcanic hazards impacting a set location. In the eruption levels of the multi-foundation system the hazard is defined according to the spatial extent of hazardous areas (similar to a hazard map), which could be determined using a fixed likelihood. The lower two levels of the multi-foundation system are based on a foundation of phenomena.

Benefits and difficulties with each of the different foundations were primarily identified by the research participants and are described below.

\section{Phenomena foundation}

A phenomenon-based VAL system divides the continuum of the intensity of volcanic activity directly into levels (Figure 3) with consideration of the proportion of the number of levels reflecting unrest and eruption. A lower level of uncertainty was thought to be involved in using a foundation of volcanic phenomena than in using a foundation of hazard, risk, or magmatic processes. As stated by one participant, the phenomena-based system is thought to be "the system that is truest to the science and conveys what the volcanoes are doing without added layers of interpretation" (Sc). Communicating this first step in the process enables the information to be appropriate for a wider range of volcanic environments, risk settings, and end-users. Furthermore, participants stated that the opportunity for subjectivity to influence the VAL decision would be minimised, and the time it takes to determine the VAL may be shorter.

Difficulties with retaining the phenomena foundation, as identified by interview participants, are that some endusers find it difficult to interpret the information into meaningful contributions to hazard planning and decisionmaking; it is very difficult to accurately set the VAL during a short-lived eruption when it is based on what is currently observable; and it is a challenge to create one system that accurately reflects the wide range in intensity of potential volcanic activity at all of New Zealand's volcanoes.

\section{Magmatic processes foundation}

One scientist participant suggested basing the VAL system on magmatic processes, inferred through the interpretation of monitoring data. This foundation essentially reflects where the magma is in the volcanic system. A benefit of this foundation is that it includes the scientific interpretation process, providing end-users with potentially more useful information. Additionally, it is one step closer to providing eruption forecasts within the VAL system. Related information (such as phenomena likely to be seen at each level, and associated hazards) could be included in the system, derived from each level. However, a number of scientist participants identified difficulties in utilising a process-based system. There would be a reliance on having accurate models for all of New Zealand's volcanoes, which is currently not the case. It was also stated by a scientist from GNS Science that using this system "would imply that at any time we know where the magma is", effectively understating uncertainty. The threat of retrospectively being proven 'wrong' was an uncomfortable consideration for some scientist participants. Due to a reliance on monitoring results and the uncertainties associated with processes and models, it is thought that there would be significant delays for scientists to decide on the most appropriate magmatic model, and therefore on the VAL. One enduser participant stated that this foundation is "too dependent [on] knowledge of process. As we saw at Te Maari [Tongariro] it might take months to get a handle 


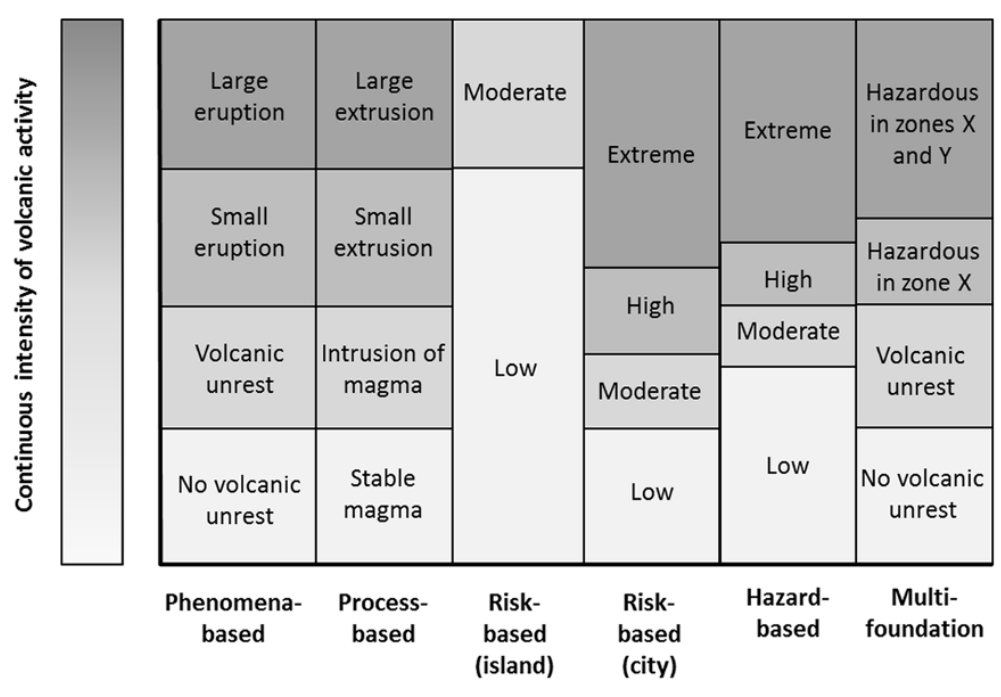

Example alternative foundations of Volcanic Alert Level systems

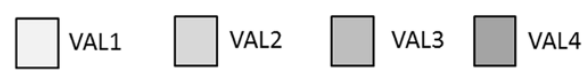

Figure 3 Differing divisions between levels in a VAL system depending on the foundation used. Legend: Each column represents a different foundation of a VAL system relative to a continuous scale of volcanic activity. The risk-based system is demonstrated for an unpopulated island volcano as well as for a volcano situated within a city.

on that. Adequate knowledge may come well after the time an alert system is most needed". An additional challenge is that some people (from all roles) who vote for the VAL at GNS Science can find it difficult to understand the models, discussions involving specific phenomena outside of their own specialities, and the implications of those phenomena on the model. The inclusion of underlying volcanic processes and models are also likely to be incomprehensible to the vast majority of end-users, leading to participants questioning the purpose of their inclusion in the VAL system.

Once the levels are divided based on the state of magma, and the accompanying information has been added, a participant noted that the processes column could be decoupled and voters could determine the VAL based on the accompanying information. Regarding the de-escalation phase of a volcanic crisis, the process-based system would require a change in concept on how a VAL system is used due to lengthy magma residence times. A wide range of potential hazards would relate to each level in a process-based VAL system, which may not be very useful for end-users: "[the process-based VAL system is] not focussed on... what the likely consequences are. Focussing on the processes makes sense from a science perspective but is quickly lost in the world of non-scientists" (EU).

\section{Risk foundation}

A system with a foundation of risk would consider the likelihood of volcanic hazards causing an impact on society. Two hypothetical examples are provided for the same (subjectively determined) risk-based system in Figure 3; the 'island' system represents a risk-based VAL system for an unpopulated island volcano incapable of high or extreme risk (such as unpopulated Macauley Island, New Zealand), and the 'city' system represents the same risk-based VAL system for a volcano within a city environment (such as Auckland Volcanic Field, New Zealand). As can be seen, the range of volcanic phenomena that relates to each of the levels in a risk-based system differs according to the risk environment. Probability thresholds for a set consequence (e.g., life safety) could be pre-determined by end-users for each region or individual volcano, to assist with the determination of risk levels by scientists. A benefit of a risk-based system is that it can be specific to each volcano, and more useful for end-users. Surprisingly, participants of this research favoured the risk-based system the least of the five foundations. This appeared to be due to the high level of uncertainty involved in ascertaining risk, and perhaps a lack of experience with this type of foundation. Further investigation of perceptions of risk as a foundation for alert level systems would be beneficial. As risk assessment capabilities for volcanology develop in the future, it may be that this foundation grows in appeal for scientists and end-users. If so, it will require careful coordination between scientists and end-users to select the most appropriate risk metric, acceptable (and tolerable) risk thresholds, and determination of common terminology to avoid misinterpretations. 


\section{Hazard foundation}

Consideration of a hazard foundation was suggested by some interview participants. Hazard assessments are based on information of past activity (from the geological and historical records), and the understanding of underlying processes and models. The method used to ascertain the level of short-term hazard may include the interpretation of monitoring data, and its application to conceptual models. This in turn would suggest styles of potential future eruption activity with associated hazards. The level of hazard can then be based subjectively on this understanding. Depending on the definition of 'hazard' used, the levels could be determined according to likelihood (such as the hazard-based system in Figure 3) or spatial extent of hazards (as in the multi-foundation example in Figure 3). Some participants thought that a hazard-based system would be useful for end-users, allowing them to directly associate their response decisions with the alert levels. It would also allow one system to be used for a range of volcanic settings. A difficulty with using a hazard-based system that was identified by the researchers includes the possibility for confusion with the spatial extent of hazards in hazard maps. Thresholds of probability for levels of hazard will need to be carefully considered prior to an event, requiring coordination with various end-users in a variety of roles.

\section{Multi-foundation}

Combining multiple foundations allows one to draw on the benefits of each system and minimise their individual weaknesses. Desires expressed by interview participants to focus on the state of activity during unrest and then change the focus to the spatial constraints of hazards during eruptions (particularly long-term eruptions) were particularly considered by the researchers while creating a multi-foundation system. The spatial extent of hazard zones (labelled X and Y in Figure 3) can be predetermined with end-users; the inclusion or exclusion of infrastructure and communities in zones incorporates an element of risk. The consequential interaction of endusers and scientists to develop this system was seen by participants as a positive attribute. Another benefit is the possibility to use this system in both escalation and de-escalation of a volcanic crisis. A major advantage of this system is the increase in guidance given to endusers on what actions they should take by stating the point at which life is at risk, while retaining appropriate roles and responsibilities between scientists and endusers. Maps displaying the hazard zones would need to be carefully developed to replace the existing (or future) hazard map for each volcano. Changing the extent of hazard zones over time could become a difficulty due to version control of associated hazard maps. Additionally, the spatially controlled hazard-based system is limited in the number of hazard zones that could be depicted, as each zone is related to a level on the VAL system, and the overall number of levels is restricted. This system refers to the area(s) which may be affected by volcanic hazards, and does not indicate the relative levels of hazard between zones.

\section{Selection of a foundation}

Analysis of the mean rank provided by participants during the feedback process resulted in the recognition that end-users slightly prefer the multi-foundation system, which includes both phenomena and hazards, while scientists have a clear preference for the phenomena-based system (Table 1).

In addition to the ranking of example systems, participants suggested alternative combinations of foundations. In particular, a phenomena-based system with the incorporation of hazard information was seen as being potentially beneficial. One end-user participant described the reason for this preference, which was to provide the context surrounding the hazard information:

\section{"The phenomenon-based system helps me understand what is going on and the relative severity of the event. The hazard-based system sets out clearly what needs to be done as a consequence. In terms of my CDEM responsibilities, we need both - people get twitchy about instructions given without context and justification - in today's world expert authority is treated with suspicion. So you need to be able to say 'why' as well as 'what".}

Hazard information is included in a number of VAL systems worldwide, including those used by scientists at Popocatépetl, Mexico (De la Cruz-Reyna and Tilling 2008), Japan Meteorological Agency, JMA (2014), Philippine Institute of Volcano and Seismology, PHIVOLCS (2014), and Monsterrat Volcano Observatory, Caribbean Islands, MVO (2014). Despite the inclusion of hazard information, the system can still be based on a foundation of phenomena. This is different to the multi-foundation system, which is based on phenomena in the lower levels, before switching to a hazard-based system for the levels representing eruptions. Some foundations have natural divisions between levels at the same place as other foundations (such as the phenomena-based and process-based systems in Figure 3), which can make it difficult to distinguish the foundation of the system.

In summary, there are a number of possible foundations on which to build VAL systems. The selection of the basis of a VAL system requires consideration of the end-users' information needs, and what scientists can reasonably achieve with the current state of knowledge and monitoring techniques. 
Table 1 Ranking analysis results for five potential VAL system foundations

\begin{tabular}{|c|c|c|c|c|c|c|}
\hline & & \multicolumn{5}{|c|}{ Foundation of VAL System } \\
\hline & & Phenomena-based & Hazard-based & Process-based & Risk-based & Multi-foundation \\
\hline \multirow[t]{5}{*}{ End-users $(n=8)$} & Subtotal (sum of ranks) & 24 & 22 & 24 & 29 & 21 \\
\hline & Mean of subtotal & 3.00 & 2.75 & 3.00 & 3.63 & 2.63 \\
\hline & Number of counts in position 1 & 1 & 2 & 2 & 1 & 2 \\
\hline & Number of counts in position 1 or 2 & 3 & 3 & 4 & 2 & 4 \\
\hline & Number of counts in position 1 or 2 or 3 & 4 & 6 & 5 & 3 & 6 \\
\hline \multirow[t]{5}{*}{ Scientists $(n=9)$} & Subtotal (sum of ranks) & 17 & 25 & 25 & 40 & 28 \\
\hline & Mean of subtotal & 1.89 & 2.78 & 2.78 & 4.44 & 3.11 \\
\hline & Number of counts in position 1 & 5 & 0 & 2 & 0 & 2 \\
\hline & Number of counts in position 1 or 2 & 6 & 5 & 4 & 1 & 2 \\
\hline & Number of counts in position 1 or 2 or 3 & 8 & 6 & 6 & 1 & 6 \\
\hline \multirow{5}{*}{$\begin{array}{l}\text { All participants } \\
(n=17)\end{array}$} & Total (sum of ranks) & 41 & 47 & 49 & 69 & 49 \\
\hline & Overall mean & 2.41 & 2.76 & 2.88 & 4.06 & 2.88 \\
\hline & Number of counts in position 1 & 6 & 2 & 4 & 1 & 4 \\
\hline & Number of counts in position 1 or 2 & 9 & 8 & 8 & 3 & 6 \\
\hline & Number of counts in position 1 or 2 or 3 & 12 & 12 & 11 & 4 & 12 \\
\hline
\end{tabular}

Foundations were ranked by participants from position 1 (highest preference) to position 5 (lowest preference). Foundations with lower subtotals, totals and means are preferred by participants. The number of times a foundation was ranked in the top three positions is also indicated, where the higher the number of counts, the more preferred the foundation is.

\section{Inclusion of forecasting}

Many end-user and scientist participants expressed support for the inclusion of forecasting in the VAL system, including this scientist participant:

"What the [end-users] are telling us is they want to know what's happening next and we've got no way, using the scale, at least, of signalling that. The argument is often that we use the Bulletins to flesh out that information, but the way we do it currently, I don't think many people read the bulletins necessarily or understand them or don't read between the lines. I think it needs to be a bit more explicit in which way we are going - up or down".

Other participants stated that the incorporation of forecasting information in the VAL system would be challenging due to the high level of uncertainty involved with forecasting, and the threat to the credibility of scientists should the volcano not erupt. Language reflecting uncertainty could be incorporated, however the language used is often difficult to interpret and keep consistent between groups (e.g., as reviewed by Doyle et al. 2011), impacting effective and consistent decision-making. Another difficulty is the need for a forecast to include a timeframe in order to be accurate. This information, along with the magnitude or intensity of forecasted activity, would need to be stated in generic terms within the VAL system in order to suit all situations, risk settings, and volcanoes in New Zealand. Some scientists insist that in the short term, volcanoes are not predictable, and thus no predictive language should be included in VAL systems.

While end-users and most scientists that participated in this research would like forecasting information to be included in the revised VAL system, the challenges described above may be too difficult to overcome. Some participants suggested that forecasting information could be included in supplementary material, such as VABs, instead of within the VAL system. This information can then be included on a case-by-case basis, and appropriate uncertainties can be included (for example, in the form of scenarios), along with situation-specific information. Given the findings of this research, the inclusion of important forecasting information in VABs would require the scientists to make the forecast information explicit in the written message, as well as initiate follow-up phone calls to key end-users to ensure the message has been received. It was recommended by participants that there should be "great clarity" (EU) between observations and forecasts in messages. Additionally, the importance of regularly disseminating information was emphasised by participants, regardless of the level of uncertainty. This supports the findings of previous authors (e.g., Mileti and Sorensen 1990; Paton et al. 1999; Ronan et al. 2000; Fearnley 2011).

Implementation of a new VAL system for New Zealand A draft new VAL system was developed based on the findings of this research. The final stage of developing 
the draft system into the published version (VAL V3) took nine months. It involved multiple iterations to slightly improve the wording and presentation; to achieve ownership by the scientists; to discuss the system with multiple end-user agencies; and to consult with MCDEM. The final version (VAL V3) of New Zealand's VAL system is presented in Figure 4, and is published in the latest update of the Guide to the National CDEM Plan (MCDEM 2006, revised in June 2014). It is based on a foundation of currently occurring phenomena, and also includes hazard information to assist with end-user decision-making. It uses simple terminology that is sufficiently generic and more appropriate for the range of New Zealand's volcanoes and the VAL user groups.

The visual presentation of the table was purposefully designed to enhance understanding of the table by endusers. This includes the incorporation of light to dark shading as levels increase, the addition of prominent 'unrest' and 'eruption' labels to the left of the table, and a shaded arrow pattern that emphasises the level of volcanic activity. The colour purple was selected for the table as it is seen as being not overly reassuring, and it is not used in the ICAO ACC or volcano hazard maps (to minimise the chance of relationships being drawn between the different systems).

The new VAL system is intended to be used in an 'absolute' sense, where the intensity of activity is directly comparable between volcanoes. This follows the wishes of end-users in New Zealand who prefer the VAL system to indicate the comparable level of volcanic activity to nonscientists. It is currently envisaged that volcanoes which constantly show signs of activity (such as low levels of tremor or high heat flow with a magmatic gas component) will remain at alert level 1 (minor unrest), rather than alert level 0 . The addition of a level representing moderate to heightened unrest (alert level 2) provides an opportunity to acknowledge situations where unrest has increased in intensity and the volcano may be more likely to erupt. The three eruption levels (minor, moderate, and major) are based on approximate magnitudes of eruption. In order to guide scientific determination of these levels, examples of past activity - predominately from New Zealand, with some international examples - have been allocated to each level (examples of these are given in Table 2). Due to the comparable nature of the VAL system, Auckland Volcanic Field is unlikely to ever reach alert level 5 as, based on

\section{New Zealand Volcanic Alert Level System}

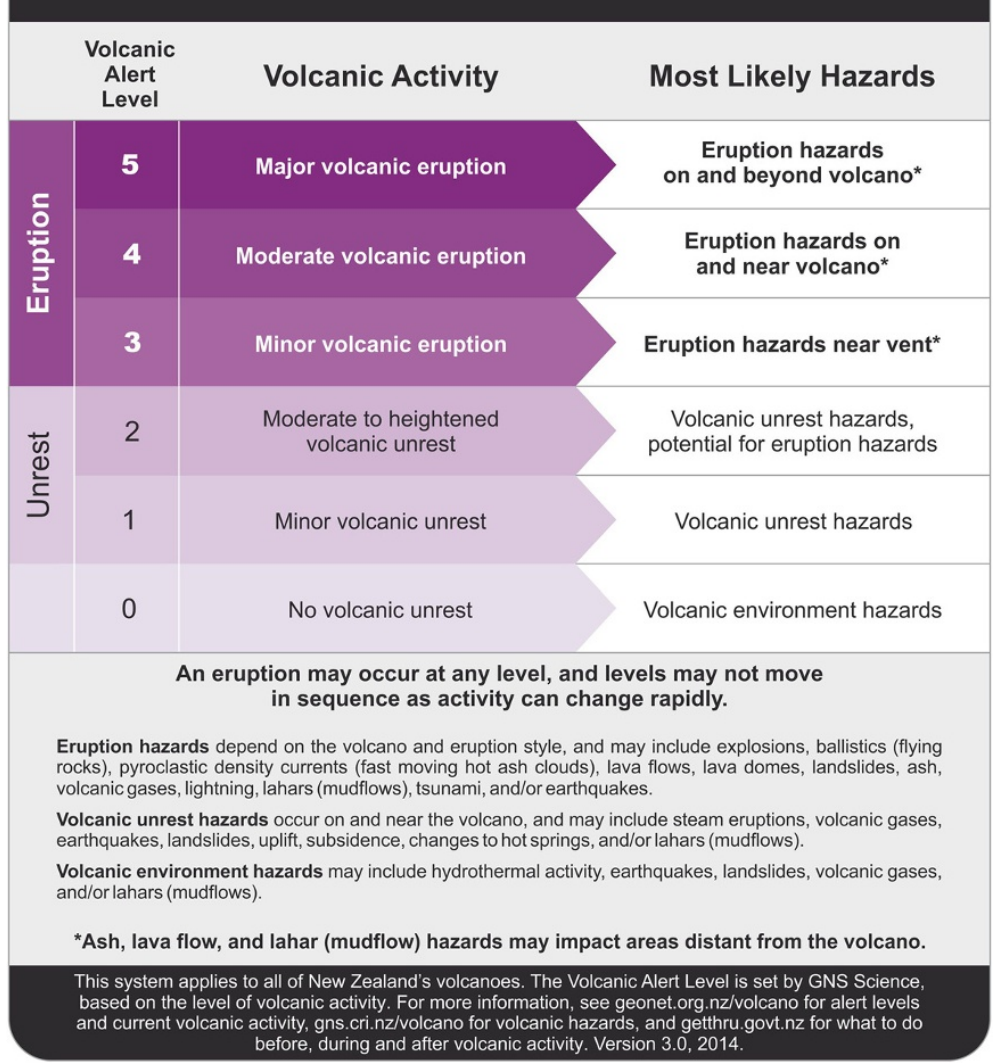

Figure 4 New Zealand's new VAL system (VAL V3), based on the findings of this research. 


\begin{tabular}{ll}
$\begin{array}{l}\text { Table } 2 \text { Typical examples of the level of activity at each } \\
\text { Volcanic Alert Level (VAL V3) }\end{array}$ \\
\begin{tabular}{ll}
\hline Volcanic Alert Level & $\begin{array}{l}\text { Example of typical activity (see the } \\
\text { GeoNet website (2014) for further details) }\end{array}$ \\
\hline $\mathbf{5}$ & Tarawera (climax of 1886 eruption) \\
$\mathbf{4}$ & Mt. Ruapehu (climax of 1995-96 eruption) \\
$\mathbf{3}$ & White Island (early August 2012) \\
$\mathbf{2}$ & White Island (late July 2012) \\
$\mathbf{1}$ & Mt. Ruapehu (May 2014); Tongariro (May 2014) \\
$\mathbf{0}$ & Auckland Volcanic Field (May 2014); Ngauruhoe \\
\hline
\end{tabular} \\
\hline
\end{tabular}

currently available geological evidence, it is very unlikely to produce an eruption similar in magnitude to those at Tarawera (1886; New Zealand), Mount St Helens (1980; USA), Pinatubo (1991; Philippines), or Taupo Volcanic Centre (232 AD; New Zealand).

Information relating to the most likely hazards that will be seen at each level of volcanic activity is included in the new VAL system, with eruption hazards described in terms of the spatial extent of near-source phenomena. Distal hazards of ashfall, lahar and lava flows may occur from any level of eruption. Additional warning systems exist for ashfall and lahars; rapid detection warning systems are in place for lahars on Mt. Ruapehu (Sherburn and Bryan 1999; Leonard et al. 2008), and ashfall hazard maps are disseminated as needed. First and foremost, the determination of the VAL is based on the overall level of volcanic activity, and not on the spatial extent of the hazards.

Once the new VAL system was finalised, a communication strategy was created in conjunction with MCDEM to inform New Zealand's population about the change of system six weeks in advance of the changeover, which occurred on 1 July 2014. Supporting documents relating to the VAL were drafted, websites were updated, and information detailing the changes was circulated to endusers (including the media, and public via social-media) by GNS Science. In conjunction with this, MCDEM updated the Guide to the National CDEM Plan where the VAL system is officially kept, and coordinated communication and training in the CDEM sector. Informal feedback from end-users on the new system has thus far been positive, however at the time of writing (August 2014), it has not yet been tested by an eruption event. Regular reviews of the new VAL system are planned, to ensure it remains as effective as possible for a changing society in the future.

\section{Conclusions}

A qualitative research methodology was used to explore New Zealand's existing VAL system (VAL V2) with the involvement of end-users and scientists. Research participants identified a number of changes that would improve the effectiveness of the communication tool. These included merging two systems (for frequently active volcanoes and reawakening volcanoes) into one for all of New Zealand's volcanoes, simplifying the terminology, and replacing the indicative phenomena information with more useful hazard information. Five foundations of VAL systems were recognised: phenomena, magmatic processes, risk, hazard, and a combination of these. There was a slight preference towards retaining a foundation of phenomena, particularly if hazard information could also be incorporated. A draft VAL system was formed based on this research, which was finalised, implemented, and introduced to New Zealand society on 1 July 2014.

Traditionally, VAL systems were developed by physical volcanologists with minimal (if any) consultation with the end-users of the system, or with social science researchers. This research has highlighted the value of incorporating the viewpoints of both end-users and scientists in the development or revision of warning tools such as VAL systems. The social science methodology used to explore New Zealand's VAL system could be applied in other countries and for other hazards to develop robust alert level systems, to ensure the needs of all users are met to the highest possible level. If utilised, the development of alert level systems suitable for the requirements of the local settings will result. The importance of considering the local context in VEWSs was also recognised by Fearnley (2011).

The limitations of this research are that the methodology is rather time consuming in order to be detailed and robust, and that the public were not included as participants. Future research could explore the New Zealand public's opinion of the VAL system. A process needs to be established to evaluate the effectiveness of the VAL system on a regular basis, incorporating the viewpoints of both end-user and scientist groups. A similar review process should also occur for other volcanology communication tools, and for warning systems for other hazards to ensure that they are as effective as possible.

\footnotetext{
Abbreviations

ACC: Aviation colour code; CDEM: Civil Defence and Emergency Management; EDS: Eruption detection system; ERLAWS: Eastern Ruapehu Lahar Alarm and Warning System; GNS: Science Institute of Geological and Nuclear Sciences, Ltd.; ICAO: International Civil Aviation Organization; MCDEM: Ministry of Civil Defence and Emergency Management; MetService: Meteorological Service of New Zealand, Ltd; VAB: Volcanic alert bulletin; VAL: Volcanic alert level; VEWS: Volcano early warning system; VONA: Volcano observatory notices for aviation.
}

\section{Competing interests}

This work was funded primarily through direct crown funding to GNS Science from the New Zealand Ministry of Business, Innovation and Economy under the Natural Hazards Research Platform, by the New Zealand Earthquake Commission (EQC) through research funding and the GeoNet project, and by the DEVORA project (co-funded by Auckland Council and 
EQC). While undertaking this research, SP gained employment by GNS Science, the organisation from which many of the research participants were interviewed and observed.

\section{Authors' contributions}

SP designed the research, undertook the data collection, analysis, and interpretation of the findings, and drafted the manuscript. GJ, VN, and DJ assisted with the project concept and design, and with editing the manuscript. BS assisted with formulating an understanding of historical aspects of New Zealand's VAL system and volcanoes, and with drafting the manuscript. All authors read and approved the final manuscript.

\section{Authors' information}

SP has a background in both geology and emergency management. The research presented in this paper was undertaken as part of her PhD research through Massey University, based at GNS Science and supervised by DJ, GJ, and VN. The draft VAL system was finalised by GNS Science following the completion of SP's research, steered by SP, BS, and GJ.

\section{Acknowledgements}

The authors would like to thank all research participants for their contribution to this research. In addition to the funding sources mentioned above, the following organisations and people are also acknowledged. The Ministry of Civil Defence and Emergency Management for supporting the development of a new VAL system; Douglas Paton, Antonia Lyons, and Emma Hudson-Doyle for their input to methodology design; Philip Carthew, from GNS Science, for graphics assistance in formulating the new VAL system; Kevin Fenaughty for GeoNet website assistance; Carina Fearnley for insightful conversations on VALs and for her helpful review of this paper; and an anonymous reviewer for their excellent suggestions.

\section{Author details}

${ }^{1}$ GNS Science, 1 Fairway Drive, Avalon, Lower Hutt, New Zealand. ${ }^{2}$ GNS Science, Wairakei Research Centre, Private Bag 2000, Taupo 3352, New Zealand. 'Massey University, Private Bag 11 222, Palmerston North 4442, New Zealand. ${ }^{4}$ Joint Centre for Disaster Research, Massey University, PO Box 756, Wellington 6140, New Zealand.

\section{Received: 5 June 2014 Accepted: 14 August 2014}

\section{Published online: 12 September 2014}

\section{References}

Adler PA, Adler P (1994) Observational Techniques. In: Denzin NK, Lincoln YS (eds) Handbook Of Qualitative Research. Sage Publications Inc., Thousand Oaks, CA, pp 377-392

Angrosino MV (2008) Recontextualizing Observation: Ethnography, Pedagogy, And The Prospects For A Progressive Political Agenda. In: Denzin NK, Lincoln YS (eds) The Sage Handbook Of Qualitative Research, 3rd edn. Sage Publications Inc, Thousand Oaks, CA, pp 161-185

Balsiger PW (2004) Supradisciplinary research practices: history, objectives and rationale. Futures 36(4):407-421, doi:10.1016/j.futures.2003.10.002

Barclay J, Haynes K, Mitchell T, Solana C, Teeuw R, Darnell A, Crosweller HS, Cole P, Pyle D, Lowe C, Fearnley C, Kelman I (2008) Framing volcanic risk communication within disaster risk reduction: finding ways for the social and physical sciences to work together. Geol Soc London Special Pub 305(1):163

Braun V, Clarke V (2006) Using thematic analysis in psychology. Qual Res in Psychol 3(2):77-101

Collins H, Evans R (2007) Rethinking Expertise. University of Chicago Press, Chicago and London

Corbin JM, Strauss A (2008) Basics Of Qualitative Research: Techniques And Procedures For Developing Grounded Theory, 3rd edn. Sage Publications Inc, Los Angeles, CA

Creswell JW (2003) Research Design: Qualitative, Quantitative, And Mixed Methods Approaches, 2nd edn. Sage Publications Inc, Thousand Oaks, CA, 246

Cronin SJ, Gaylord DR, Charley D, Alloway BV, Wallez S, Esau JW (2004) Participatory methods of incorporating scientific with traditional knowledge for volcanic hazard management on Ambae Island, Vanuatu. Bull Volcanol 66(7):652-668
De la Cruz-Reyna S, Tilling RI (2008) Scientific and public responses to the ongoing volcanic crisis at Popocatépetl Volcano, Mexico: Importance of an effective hazards-warning system. J Volcanol Geotherm Res 170(1):121-134

Denzin NK, Lincoln YS (1994) Introduction: Entering The Field Of Qualitative Research. In: Denzin NK, Lincoln YS (eds) Handbook Of Qualitative Research. Sage publications, Thousand Oaks, CA, pp 1-17

Donovan A, Oppenheimer C, Bravo M (2012a) Social studies of volcanology: knowledge generation and expert advice on active volcanoes. Bull Volcanol 74(3):677-689, doi:10.1007/s00445-011-0547-z

Donovan A, Oppenheimer C, Bravo M (2012b) The use of belief-based probabilistic methods in volcanology: scientists' views and implications for risk assessments. J Volcanol Geotherm Res 247-248:168-180

Dow K, Cutter SL (1997) Crying wolf: repeat responses to hurricane evacuation orders. Coast Manag 26(4):237-251

Doyle EE, Johnston DM, McClure J, Paton D (2011) The communication of uncertain scientific advice during natural hazard events. NZ J Psychol 40(4):39-50

Fearnley CJ (2011) Standardising the USGS Volcano Alert Level System: Acting In The Context Of Risk, Uncertainty And Complexity. Ph.D. Thesis. University College London, London, UK

Fearnley C (2013) Assigning a volcano alert level: negotiating uncertainty, risk, and complexity in decision-making processes. Environ Plan A 45(8):1891-1911

Fearnley CJ, McGuire WJ, Davies G, Twigg J (2012) Standardisation of the USGS Volcano Alert Level System (VALS): analysis and ramifications. Bull Volcanol 74(9):2023-2036

Fischhoff B (1995) Risk perception and communication unplugged: twenty years of process. Risk Anal 15(2):137-145

Fiske RS (1984) Volcanologists, Journalists, And The Concerned Local Public: A Tale Of Two Crises In The Eastern Caribbean. In: Geophysics Study Committee (ed) Explosive volcanism: inception, evolution, and hazards. National Academy Press, Washington D.C, p 170

Gardner CA, Guffanti MC (2006) U.S. Geological Survey's Alert Notification System For Volcanic Activity. U.S. Geological Survey Fact Sheet 2006-3139, U.S. Geological Survey

GeoNet (2014) GeoNet volcanic activity information. [http://geonet.org.nz/ volcano/], accessed on 8 August 2014

GNS Science and MCDEM (2009) Memorandum of Understanding between the Ministry of Civil Defence \& Emergency Management (MCDEM) and Institute of Geological and Nuclear Sciences Limited (GNS Science) for the engagement of geoscience and Civil Defence Emergency Management. Wellington, New Zealand, p 18

Haynes K, Barclay J, Pidgeon N (2007) Volcanic hazard communication using maps: an evaluation of their effectiveness. Bull Volcanol 70(2):123-138. doi:10.1007/s00445-007-0124-7

Haynes K, Barclay J, Pidgeon N (2008) The issue of trust and its influence on risk communication during a volcanic crisis. Bull Volcanol 70(5):605-621

Horlick-Jones T, Sime J (2004) Living on the border: knowledge, risk and transdisciplinarity. Futures 36(4):441-456

IDNDR Early Warning Programme Convenors (1997) Guiding Principles For Effective Early Warning. Convenors of the International Expert Groups on Early Warning. United Nations International Decade for Natural Disaster Reduction, Geneva, Switzerland

JMA (2014) Japan Meteorological Agency Volcanic Alert Level system. [http:// www.data.jma.go.jp/svd/vois/data/tokyo/STOCK/kaisetsu/English/level.html], accessed 21 May 2014

Lechner P (2012) Living With Volcanic Ash Episodes In Civil Aviation: the New Zealand Volcanic Ash Advisory System (VAAS) and the International Airways Volcano Watch (IAVW) Civil Aviation Authority of New Zealand., p 11 a

Leonard GS, Johnston DM, Paton D, Christianson A, Becker J, Keys H (2008) Developing effective warning systems: ongoing research at Ruapehu volcano, New Zealand. J Volcanol Geotherm Res 172(3-4):199-215, doi:10.1016/j.jvolgeores.2007.12.008

Mader GG, Blair ML (1987) Living with a Volcanic Threat: Response to Volcanic Hazards, Long Valley, California. William Spangle and Associates, Portola Valley, California, p 105

Martin RJ (1992) Post-Exercise Report: Exercise Nga Puia. Bay of Plenty Regional Council, Whakatane

MCDEM (2006) The Guide to the National Civil Defence Emergency Management Plan 2006. Ministry of Civil Defence \& Emergency Management, Wellington

McGuire WJ, Solana MC, Kilburn CRJ, Sanderson D (2009) Improving communication during volcanic crises on small, vulnerable islands. J Volcanol Geotherm Res 183(1-2):63-75 

volcanic risk management: the yellow alert in Quito in October 1998. GeoJournal 49(2):213-221

Miles MB, Huberman AM (1994) Qualitative Data Analysis: An Expanded Sourcebook, 2nd edn. Sage Publications, Thousand Oaks, p xiv, 338

Mileti DS, Sorensen JH (1990) Communication Of Emergency Public Warnings - A Social Science Perspective And State-Of-The-Art Assessment. Oak Ridge National Laboratory, Oak Ridge, TN, p 166

MVO (2014) Montserrat Volcano Observatory Hazard Level System for Soufriere Hills Volcano. [http://www.mvo.ms/pub/Hazard_Level_System/HLS-20111104. pdf], accessed on 21 May

Nairn IA, Scott BJ (1995) Scientific management of the 1994 Rabaul eruption: Lessons for New Zealand. Science Report 95/26. Institute of Geological \& Nuclear Sciences Limited, Lower Hutt, p 27

Newhall CG (2000) Volcano warnings. In: Sigurdsson H, Houghton BF, McNutt SR, Rymer H, Stix J (eds) Encyclopedia of Volcanoes. Academic Press, pp 1185-1197

Newhall CG, Punongbayan RS (1996) The Narrow Margin Of Successful Volcanic-Risk Mitigation. In: Scarpa R, Tilling RI (eds) Monitoring And Mitigation Of Volcanic Hazards. Spinger Verlag, San Diego, CA, pp 807-838

Paton D, Johnston DM, Houghton B (1998) Organisational response to a volcanic eruption. Disaster Prev Manage 7(1):5-13

Paton D, Johnston DM, Houghton B, Flin R, Ronan KR, Scott BJ (1999) Managing natural hazard consequences: information management and decision making. J Am Soc Prof Emerg Managers 6:37-48

Patton MQ (2002) Qualitative Research And Evaluation Methods, 3rd edn. Sage, Thousand Oaks, CA

Peräkylä A (2008) Analyzing Talk And Text. In: Denzin NK, Lincoln YS (eds) Collecting And Interpreting Qualitative Materials, 3rd edn. Sage Publications Inc, Thousand Oaks, CA, pp 351-373

Peterson DW, Tilling RI (1993) Interactions Between Scientists, Civil Authorities And The Public At Hazardous Volcanoes. In: Kilburn CRJ, Luongo G (eds) Active Lavas: Monitoring And Modelling. UCL Press, London

PHIVOLCS (2014) PHIVOLCS Taal Volcano Alert Signal. [http://www.phivolcs.dost.gov. ph/index.php?option=com_content\&view=article\&id=815\%3Ataal-volcanoalertsignal\&catid=83\%3Avolcano-alert-levels\&ltemid=86], accessed on 21 May 2014

Potter SH (2014) Communicating the Status Of Volcanic Activity in New Zealand, With Specific Application To Caldera Unrest. PhD Thesis. Massey University, Wellington, New Zealand

Ronan KR, Paton D, Johnston DM, Houghton BF (2000) Managing societal uncertainty in volcanic hazards: a multidisciplinary approach. Disaster Prev Manage 9(5):339-349

Scott BJ, Travers J (2009) Volcano monitoring in NZ and links to SW Pacific via the Wellington VAAC. Nat Hazards 51(2):263-273, doi:10.1007/s11069-009-9354-7

Sherburn S, Bryan CJ (1999) the eruption detection system: Mt. Ruapehu, New Zealand. Seismol Res Lett 70(5):505-511, doi:10.1785/gssrl.70.5.505

Sorensen JH, Gersmehl PJ (1980) Volcanic hazard warning system: persistence and transferability. Environ Manag 4(2):125-136

Stake RE (1995) The Art Of Case Study Research. Sage Publications Inc, Thousand Oaks, CA, p i-xv, 173

the GeoNet website (2014) GeoNet Volcano Alert Bulletins. [http://info.geonet. org.nz/blog/volc], accessed on 28 May 2014

UN/ISDR (2009) Terminology on Disaster Risk Reduction. United Nations International Strategy for Disaster Reduction, Geneva, Switzerland

UN/ISDR PPEW (2006) Developing Early Warning Systems, A Checklist: Third International Conference On Early Warning (EWC III), 27-29 March 2006. United Nations International Strategy for Disaster Reduction Platform for the Promotion of Early Warning, Bonn, Germany

Voight B (1990) The 1985 Nevado Del Ruiz volcano catastrophe - anatomy and retrospection. J Volcanol Geotherm Res 42(1-2):151-188

Volcanic Impact Study Group ash impact posters (2014) [http://www.gns.cri.nz/ Home/Learning/Science-Topics/Volcanoes/Eruption-What-to-do/Ash-ImpactPosters], accessed on 10 January 2014

Wolcott HF (1999) Ethnography: A Way Of Seeing, 2nd edn. AltaMira Press, Lanham, MD

doi:10.1186/s13617-014-0013-7

Cite this article as: Potter et al:: Communicating the status of volcanic activity: revising New Zealand's volcanic alert level system. Journal of Applied Volcanology 2014 3:13.

\section{Submit your manuscript to a SpringerOpen ${ }^{\odot}$ journal and benefit from:}

- Convenient online submission

- Rigorous peer review

- Immediate publication on acceptance

- Open access: articles freely available online

- High visibility within the field

- Retaining the copyright to your article

Submit your next manuscript at $>$ springeropen.com 